\title{
Domeboro Solution
}

National Cancer Institute

\section{Source}

National Cancer Institute. Domeboro Solution. NCI Thesaurus. Code C29001.

A aluminum solution with astring ent, antibacterial, and antifung al properties. Domeboro solution is a commercial preparation of modified Burow's solution, ( $5 \%$ aluminum acetate) by Bayer. Aluminum sulfate, the active ing redient of Domeboro, is attributed for this agent's bacteriostatic effect. Domeboro is used most often to cleanse irritated skin and soothe inflammation. 